\title{
PENGEMBANGAN SISTEM INFORMASI DISTRIBUSI INFORMASI SEKOLAH MELALUI SMS GATEWAY DENGAN ZACHMAN FRAMEWORK
}

\author{
Hoga Saragih ${ }^{1}$, Gusvita ${ }^{2}$, Bobby Reza ${ }^{3}$, Didik Setiyadi ${ }^{3}$ dan Rufman I. Akbar ${ }^{3}$ \\ ${ }^{\mathbf{1}}$ Fakultas Teknik dan Ilmu Komputer, Universitas Bakrie \\ Kampus Kuningan, Kawasan Epicentrum, Jl. H.R. Rasuna Said Kav. C-22 Jakarta 12920. \\ ${ }^{2}$ Program Studi Sistem Informasi, STMIK Widya Dharma \\ Jl. H.O.S Cokroaminoto No.445, Pontianak, 78111, Indonesia. \\ ${ }^{3}$ Program Pasca Sarjana, STMIK Eresha \\ Email: hogasaragih@gmail.com
}

\begin{abstract}
Abstrak
Dunia pendidikan memanfaatkan perkembangan teknologi informasi dan komunikasi untuk semakin meningkatkan kualitas pendidikan. Salah satunya dengan cara mengembangkan Sistem Informasi distribusi informasi sekolah melalui SMS Gateway. Pendistribusian informasi melalui SMS Gateway diharapkan dapat mengoptimalkan sistem pendistribusian informasi yang sedang berjalan di SDS Gembala Baik I dan memudahkan orang tua murid dalam pengaksesan informasi sekolah. Pada penelitian ini dihasilkan sebuah rancangan sistem informasi distribusi informasi sekolah melalui SMS Gateway dengan alur proses perancangan menggunakan pendekatan Zachman Framework. Perancangan dimulai dengan dengan melakukan identifikasi kebutuhan sistem yang dimodelkan dengan menggunakan Unified Modeling Language (UML), perancangan antar muka pengguna menggunakan Graphical User Interface (GUI) dan perancangan basis data. Hasil dari perancangan Sistem Informasi distribusi informasi Sekolah ini mempunyai tiga tab menu utama yaitu tab menu SMS Server, Pengumuman Umum dan Pengumuman Kelas. Hasil dari perancangan ini dapat digunakan sebagai acuan yang terstruktur untuk pembuatan coding program dan uji coba pengembangan sistem informasi distribusi informasi sekolah melalui SMS Gateway di SDS Gembala Baik I Pontianak.
\end{abstract}

Kata Kunci: Sistem Informasi, Distribusi Informasi Sekolah, SMS Gateway, Zachman Framework, Unified Modeling Language (UML), Graphical User Interface (GUI)

\begin{abstract}
Education world makes use of development in technology of information and communication to improve its quality. One example of this is the school effort in improving the distribution system of School information by using SMS Gateway. The writer expects that SMS Gateway will be able to optimize the distribution of information that SDS Gembala Baik I is having at the present and to help parents in accessing School information. This research results in a design of information distribution system of a School by using SMS Gateway. The writer uses Zachman Framework approach in determining steps in the design. The writer starts the design by identifying the need of a system modelled on Unified Modeling language (UML). Later, she designs User Interface using GUI and finally she designs a database. The design that the writer makes has three main menu tabs: SMS Server menu tab, School Public Announcement menu tab and Class Announcement menu tab. The result of the design can be used as a structured guide for making program coding and for trying up the development system of school information distribution by using SMS Gateway in SDS Gembala Baik I Pontianak.
\end{abstract}

Keywords: Information System, School Information Distribution, SMS Gateway, Zachman Framework, Unified Modeling language (UML), Graphical User Interface (GUI)

\section{Pendahuluan}

Seiring dengan perkembangan teknologi yang berkembang pesat, hampir semua sektor kehidupan saat ini memanfaatkan teknologi informasi untuk mendukung pekerjaan operasional supaya menjadi lebih baik. Dunia pendidikan juga tidak mau ketinggalan mengikuti 
perubahan dan perkembangan teknologi informasi. Hal ini dilakukan untuk meningkatkan kualitas sistem pendidikan dan meningkatkan kepuasan kepada masyarakat. Dengan meningkatnya kualitas sistem pendidikan diharapkan terjadi peningkatan minat bagi calon siswa untuk memilih instansi pendidikan tersebut.

Peningkatan kualitas pendidikan dapat dilakukan dengan cara meningkatkan Sistem Informasi Sekolah, terutama dalam hal penyampaian dan penerimaan informasi dari dan kepada orang tua murid selaku mitra kerja Sekolah yang juga berperan penting dalam kelancaran proses belajar mengajar dan peningkatan prestasi anak di Sekolah.

Penelitian yang di lakukan di salah satu Sekolah Dasar Malaysia, mengangkat topik perlunya peran dan kolaborasi antara orang tua dan guru di dunia pendidikan, keterlibatan orang tua di dalam pendidikan anak-anaknya diyakini dapat semakin meningkatkan pencapaian dan performansi akademik anak mereka di Sekolah, maka dari itu, orang tua sangat memerlukan informasi mengenai pendidikan anak mereka yang dapat diakses atau diperoleh dengan cepat dan mudah [1]. Penyaluran informasi dari pihak Sekolah ke orang tua murid dapat dilakukan dengan memanfaatkan website untuk media penyampaian informasi atau pun dengan melalui SMS Gateway. Dari hasil survei yang dilakukan, ternyata orang tua murid lebih menyukai apabila informasi Sekolah yang berbasis pada pemanfaatan teknologi disalurkan melalui Short Message Service (SMS) daripada menggunakan website, hal ini dikarenakan mereka tidak memiliki banyak waktu untuk mengakses website disaat sela pekerjaan harian mereka [2] .

Short Message Service (SMS) merupakan sebuah layanan yang banyak diaplikasikan pada sistem komunikasi tanpa kabel, memungkinkan dilakukannya pengiriman pesan dalam bentuk alphanumeric dan merupakan feature wajib pada sebuah handphone [3]. Sedangkan SMS Gateway adalah sebuah perangkat lunak yang menggunakan bantuan komputer dan memanfaatkan teknologi seluler yang diintegrasikan untuk mendistribusikan pesanpesan yang di generate lewat Sistem Informasi melalui media SMS yang ditangani oleh jaringan seluler [4]. Secara umum SMS Gateway adalah sebuah sistem yang dipergunakan untuk memudahkan seseorang atau suatu organisasi untuk dapat mengirimkan pesan SMS yang sama dalam waktu yang bersamaan pada banyak orang.

Pemanfaatan SMS Gateway sebagai alternatif penyaluran informasi Sekolah dapat dilihat dari beberapa penelitian yang pernah dilakukan. Misalnya penelitian mengenai pemanfaatan aplikasi SMS Gateway untuk penginformasian jam kehadiran dan kepulangan murid, prilaku murid di Sekolah [5], data absensi dan kegiatan Sekolah [6] kepada orang tua murid. Untuk jenjang pendidikan yang lebih tinggi, juga pernah dilakukan penelitian mengenai pemanfaatan SMS Gateway untuk pengembangan Sistem Informasi monitoring tugas akhir [7] serta penginformasian ruang ujian dan jadwal ulangan serta perubahannya [8].

Dari hasil survei dan penelitian-penelitan yang pernah dilakukan di atas dapat dapat diambil kesimpulan bahwa sektor pendidikan cukup menaruh perhatian terhadap perlunya peran serta orang tua dalam pendidikan anak mereka dan perlunya pengembangan Sistem Informasi pendistribusian informasi dari pihak Sekolah kepada warga Sekolah untuk semakin mengingkatkan komunikasi, kerjasama antara kedua belah pihak dengan tujuan saling membantu dalam hal monitoring pendidikan dan kegiatan belajar mengajar yang akan diikuti oleh peserta didik [9].

SDS Gembala Baik I adalah satu di antara banyak Sekolah swasta di Pontianak yang memiliki kebutuhan penyampaian informasi Sekolah secara cepat dan tepat sasaran, langsung kepada orang tua murid. Hal ini dikarenakan dari setiap alternatif penyampaian informasi Sekolah yang biasa dilakukan (seperti pengumuman yang ditempel di papan pengumuman, pengumuman langsung di kelas, dan surat edaran Sekolah) sering kali tidak mendapatkan feedback yang maksimal.

Banyak sekali murid lupa akan informasi yang pernah diumumkan oleh pihak Sekolah ataupun, seringkali informasi tidak disampaikan kembali ke orang tua murid, surat edaran hilang karena tercecer dan bisa juga dengan sengaja dihilangkan. Faktor lainnya adalah dari pihak orang tua murid sendiri tidak meluangkan waktu atau menyempatkan diri memperhatikan pengumuman yang tertempel di papan pengumuman atau catatan guru di buku penghubung anaknya. Sehingga pada hari yang ditentukan sehubungan dengan batas pengumuman, banyak murid yang tidak siap.

Salah satu contohnya, walaupun setiap hari diumumkan dan dihimbau oleh guru untuk menggerjakan Pekerjaan Rumah (PR), tetapi pada saat hari pengumpulan tugas masih juga ditemukan banyak murid yang lupa mengerjakan pekerjaan rumah (PR) mereka. Setiap hari, sudah menjadi pemandangan biasa, bahwa ada saja anak-anak dihukum di depan kelas hanya karena tidak mengerjakan tugas atau PR, hal ini menjadi suatu indikator bagi peneliti bahwa adanya permasalahan Sekolah sehubungan dengan 
pendistribusian informasi Sekolah. Oleh karenanya, dengan melihat pada pemanfaatan teknologi informasi dan komunikasi saat ini dan didasarkan pada penelitian-penelitian yang pernah dilakukan sehubungan dengan pendistribusian informasi Sekolah, maka yang peneliti kerjakan untuk penelitian kali ini adalah mengembangkan Sistem Informasi distribusi informasi Sekolah SDS Gembala Baik I melalui SMS Gateway. Penelitian ini bermaksud untuk mengoptimalkan penyampaian informasi dan dalam melakukan penelitian ini, peneliti menggunakan pendekan Zachman Framework dan permodelan menggunakan Unified Modelling Language (UML).

Informasi yang dikirimkan dari pihak Sekolah ke orang tua murid berupa informasi umum yaitu sehubungan dengan pengumuman libur Sekolah, himbauan Sekolah, acara atau lomba yang akan diadakan Sekolah, serta informasi kelas yang berhubungan dengan informasi adanya tugas harian dan jadwal ulangan.

Pengembangan Sistem Informasi distribusi informasi Sekolah melalui SMS Gateway diharapkan dapat mengatasi kendala-kendala distribusi informasi Sekolah yang sedang berjalan serta memberi kemudahan juga bagi orang tua murid untuk dapat mengakses kembali informasi, jika terjadi kondisi dimana informasi yang pernah didistribusikan Sekolah hilang dikarenakan ketidaksengajaan dalam penghapusan pesan. Untuk mendapatkan informasi Sekolah kembali, orang tua dapat mengirimkan SMS dengan format SMS yang telah ditentukan sebelumnya kemudian sistem SMS Gateway dari pihak Sekolah akan membalas SMS orang tua murid sesuai dengan request informasi yang diperlukan [10].

Informasi yang didistribusikan dan dapat diakses langsung oleh orang tua ini sangat penting mengingat bahwa peran serta orang tua murid dalam kelancaran proses belajar mengajar di tingkat Sekolah Dasar sangatlah besar, karena murid-murid masih di jenjang umur terbilang masih kecil ini masih membutuhkan bantuan, pengarahan, dukungan serta perhatian yang besar dari orang tua mereka [11]. Informasi yang disampaikan kepada orang tua murid menjadi dasar bagi orang tua untuk memperhatikan kesiapan anaknya dalam mengikuti pendidikan di Sekolah, baik dari segi kelengkapan peralatan Sekolah yang diperlukan serta mental anaknya dalam menghadapi ulangan ataupun kegiatan pembelajaran yang akan diterima di Sekolah nantinya.

Pengembangan Sistem Informasi distribusi informasi Sekolah melalui SMS Gateway di SDS Gembala Baik I dapat dilakukan dengan cara mengembangkan sendiri aplikasi SMS Gateway tanpa terikat dengan salah satu jasa dari provider manapun, sehingga pihak Sekolah dapat lebih fleksibel mengelola informasi yang akan didistribusikan [12] dan pembiayaan dalam pendistribusian informasi [3]. Pembangunan aplikasi SMS Gateway ini mungkin untuk dilakukan oleh pihak Sekolah sendiri mengingat saat ini banyak sumber pengetahuan untuk pembuatan aplikasi SMS Gateway, yakni dari buku-buku bacaan maupun sumber-sumber informasi yang berasal dari internet.

\section{Rancangan Sistem}

Penelitian ini bertujuan untuk menghasilkan rancangan Sistem Informasi distribusi informasi Sekolah melalui SMS Gateway dengan pendekatan Zachman Framework. Tahapan penelitian dimulai dari mendefinisikan permasalahan, kemudian melakukan analisis dan disain menggunakan pendekatan Zachman Framework dengan menentukan ruang lingkup sistem (business scope) yang meliputi seluruh data, proses dan konfigurasi jaringan sistem dilanjutkan dengan pembuatan rancangan business model yaitu tata laksana sistem yang digambarkan dengan use case diagram dan membuat model Sistem Informasi (information system model) dalam bentuk class diagram, activity diagram dan sequence diagram. Tahap terakhir yang harus dilakukan adalah membuat technology model yaitu rancangan antar muka pengguna dengan Graphical User Interface (GUI) dan perancangan database.

Sistem informasi dalam hal penyampaian informasi sekolah kepada murid dan orang tua murid menjadi sangat penting untuk diperhatikan, karena hal ini menyangkut kelancaran berlangsungnya proses belajar mengajar sekolah serta peningkatan prestasi peserta didik. Informasi dari pihak sekolah kepada orang tua murid seharusnya dilakukan secara berkala dengan cara tatap muka, sehingga informasi dapat disampaikan secara menyeluruh dan langsung, serta memungkinkan adanya diskusi dan dialog antara pihak sekolah dan orang tua murid. Akan tetapi karena keterbatasan fasilitas sarana dan prasarana sekolah, antara lain tidak ada aula yang dapat menampung cukup banyak orang, maka dari pihak sekolah mengupayakan penyampaian informasi melalui surat edaran, pengumuman yang ditempel di papan pengumuman, dan pengumuman langsung ke murid di setiap kelas. Selain itu, wali kelas menyampaikan informasi mengenai perkembangan atau kendala belajar yang dihadapi peserta didik di kelasnya melalui buku penghubung. Informasi yang disampaikan 
melalui buku penghubung ini akan dibaca oleh orang tua murid di rumah.

Dari hasil observasi dan wawancara dengan kepala sekolah mengenai penerapan sistem informasi dalam hal pendistribusian informasi yang berjalan, dapat disimpulkan bahwa pendistribusian informasi melalui cara-cara tersebut di atas, belum tergolong sebagai penyampaian informasi yang efektif. Hal ini dapat dilihat dari masih banyak orang tua murid yang melakukan konfirmasi dan klarifikasi baik melalui SMS maupun via telepon kepada kepala sekolah dan wali kelas mengenai pengumuman yang telah disampaikan, karena kebanyakan orang tua tidak menyempatkan diri untuk melihat pengumuman yang tertempel di papan pengumuman. Banyak anak yang tidak membawa buku penghubung atau bahkan buku penghubungnya hilang dan kemudian dikarenakan kesibukan atau ketidakperdulian orang tua maka catatan-catatan perbaikan, himbauan dan saran dari guru kepada orang tua murid yang disampaikan melalui buku penghubung sering tidak ditindaklanjuti. Terakhir, surat edaran yang dibagikan langsung kepada murid tercecer atau tidak disampaikan langsung kepada orang tuanya.

Peneliti melakukan pendataan terhadap banyaknya murid yang tidak membawa buku penghubung dan pendataan terhadap pengembalian lembar konfirmasi penerimaan surat edaran sekolah untuk memperkuat hasil observasi dan wawancara dengan kepala sekolah.

Buku penghubung berfungsi sebagai media komunikasi dan informasi antara pihak sekolah dengan orang tua murid. Di SDS Gembala Baik I, buku penghubung hanya diberlakukan pada murid kelas 1 sampai dengan kelas 3, sedangkan untuk kelas 4 sampai kelas 6 , pihak sekolah tidak mengharuskan lagi para murid untuk membawa buku penghubung, dengan pertimbangan bahwa pada usia 9 sampai dengan 11 tahun, tingkat kesadaran murid diyakini mampu untuk mendengar dan menyerap informasi secara langsung dengan baik. Murid kelas 4 sampai dengan kelas 6 , diharapkan sudah bisa mengeri tanggung jawab dan mengingat dengan baik informasi yang disampaikan melalui pengumuman langsung.

Pendataan jumlah murid yang tidak membawa buku penghubung dilakukan pada tanggal 24 April 2012, untuk murid kelas 1, 2 dan 3 dengan total jumlah murid sebanyak 386 orang. Dari pendataan didapatkan data jumlah murid yang tidak membawa buku penghubung sebagaimana dapat dilihat pada Tabel I.
TABEL I

PENDATAAN MURID YANG TIDAK MEMBAWA BUKU PENGHUBUNG

\begin{tabular}{lccccc}
\hline Kelas & A & B & C & D & Jumlah Murid \\
\hline 1 & 8 & 11 & 4 & 3 & 26 \\
\hline 2 & 5 & 0 & 12 & 10 & 27 \\
\hline 3 & 13 & 25 & 15 & 1 & 54 \\
\hline \multicolumn{5}{c}{ Total Murid yang Tidak Membawa } \\
Buku Penghubunng
\end{tabular}

Dari data yang dikumpulkan didapatkan bahwa masih terdapat sekitar 107 murid yang tidak membawa buku penghubung meskipun sudah diharuskan untuk membawa. Hal ini menunjukan bahwa pendistribusian informasi sekolah melalui media buku penghubung mengalami kendala dimana banyak anak yang tidak membawa buku penghubung, berarti informasi dari pihak sekolah tidak sampai secara utuh ke orang tua murid.

Adapun persentase dari jumlah murid yang tidak membawa buku penghubung dibandingkan dengan murid yang membawa buku penghubung dapat dilihat pada Gambar 1 .
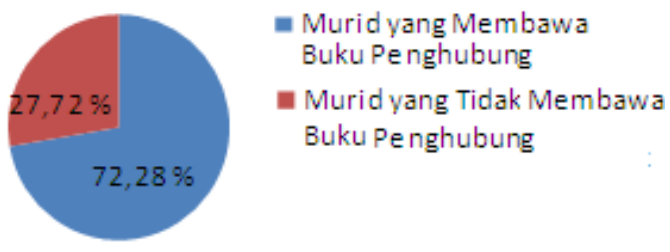

Gambar 1. Diagram pie pendataan murid yang tidak membawa buku penghubung

Pendistribusian informasi sekolah bagi siswa kelas 4, 5 dan 6 dilakukan melalui pengumuman langsung dan surat edaran sekolah. Surat edaran sekolah dilengkapi dengan lembar konfirmasi yang harus ditandatangani orang tua dan dikembalikan kepada pihak sekolah sebagai bukti telah menerima dan membaca informasi. Untuk melihat efektifitas dan dampak informasi yang disampaikan melalui pengumuman langsung, peneliti melakukan pendataan terhadap pengembalian lembar konfirmasi surat edaran yang disebarkan pada tanggal 25 April 2012 dan yang harus dikembalikan oleh murid pada tanggal 26 April 2012. Pendataan dilakukan pada murid kelas 4 dan 5 dengan total jumlah murid sebanyak 293 orang. Adapun data yang didapatkan sehubungan pengumpulan kembali lembar konfirmasi ditampilkan pada Tabel II. 
TABEL II

PENDATAAN MURID UNTUK PENGUMPULAN LEMBAR KONFIRMASI SURAT EDARAN

\begin{tabular}{llll}
\hline Kelas & $\begin{array}{c}\text { Surat } \\
\text { Edaran } \\
\text { yang } \\
\text { Dibagikan }\end{array}$ & $\begin{array}{c}\text { Lembar } \\
\text { Konfirmasi } \\
\text { Terkumpul }\end{array}$ & $\begin{array}{c}\text { Lembar } \\
\text { Konfirmasi } \\
\text { Belum } \\
\text { Terkumpul }\end{array}$ \\
\hline 4 & 145 & 112 & 33 \\
5 & 148 & 98 & 50 \\
& Total & 210 & 83 \\
\hline
\end{tabular}

Dari data yang tekumpul menunjukan bahwa penyampaian informasi melalui pengumuman langsung belum efektif, dimana masih terdapat 83 murid yang belum mengembalikan lembar konfirmasi pada waktu yang sudah ditentukan.

Adapun persentase dari jumlah murid yang mengembalikan lembar konfirmasi dibandingkan dengan murid yang belum mengembalikan lembar konfirmasi dapat dilihat pada Gambar 2.

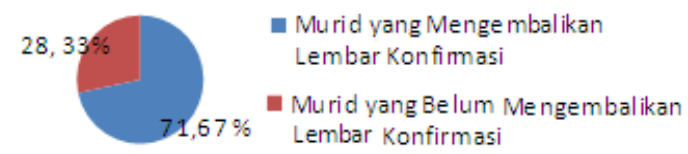

Gambar 2. Diagram pie pendataan murid untuk pengumpulan lembar konfirmasi surat edaran

Dari wawancara, observasi dan pendataan yang dilakukan oleh peneliti dapat disimpulkan bahwa sistem informasi pendistribusian informasi sekolah melalui cara-cara tersebut di atas, belum maksimal karena orang tua yang menjadi target penyampaian informasi tidak mendapatkan informasi secara langsung dan lengkap.

Berdasarkan kesimpulan di atas maka peneliti mengembangkan sistem informasi distribusi informasi sekolah melalui SMS Gateway dimana dari pengembangan sistem informasi ini memungkinkan Sekolah untuk menyebarkan informasi dengan cepat dan tepat langsung ke orang tua murid, serta orang tua murid juga dimungkinkan untuk dapat mengakses informasi Sekolah dengan mudah, kapan dan dimana saja.

Adapun kebutuhan data-data yang diperlukan dalam Sistem Informasi distribusi informasi Sekolah melalui SMS Gateway dapat dilihat pada Tabel III.

Proses yang dibutuhkan pada Sistem Informasi distribusi informasi Sekolah melalui SMS Gateway dapat dilihat pada Tabel IV.

Sistem distribusi informasi Sekolah melalui SMS Gateway yang akan dikembangkan memiliki konfigurasi jaringan sistem seperti terlihat pada Gambar 3.
TABEL III

ANALISA KEBUTUHAN DATA

\begin{tabular}{|c|c|c|}
\hline No & Nama Data & Atribut Data \\
\hline 1 & Tipe Pengumuman & $\begin{array}{l}\text { IDTipePengumuman, } \\
\text { JenisPengumuman, } \\
\text { NamaPengumuman }\end{array}$ \\
\hline 2 & Pengumuman Umum & $\begin{array}{l}\text { NoPengumuman_U, } \\
\text { TglPengumuan_U, } \\
\text { IDTipePengumuman, } \\
\text { IsiPengumuman_U }\end{array}$ \\
\hline 3 & Pengumuman Kelas & $\begin{array}{l}\text { NoPengumuman_K, } \\
\text { TglPengumuan_K, } \\
\text { IDTipePengumuman, } \\
\text { IDKelas, } \\
\text { IDMataPelajaran,IsiPengumu } \\
\text { man_K }\end{array}$ \\
\hline 4 & Kelas & $\begin{array}{l}\text { IDKelas, NamaWaliKelas, } \\
\text { JlhSiswa }\end{array}$ \\
\hline 5 & Mata Pelajaran & $\begin{array}{l}\text { IDMataPelajaran, } \\
\text { NamaMataPelajaran }\end{array}$ \\
\hline 6 & Pesan Keluar Umum & $\begin{array}{l}\text { IDPesanKeluar_U, } \\
\text { NoPengumuman_U, } \\
\text { TglWaktuKirimPesan_U, } \\
\text { NIS, StatusPesan_U }\end{array}$ \\
\hline 7 & Pesan Keluar Kelas & $\begin{array}{l}\text { IDPesanKeluar_K, } \\
\text { NoPengumuman_K, } \\
\text { TglWaktuKirimPesan_K, } \\
\text { NIS, StatusPesan_K }\end{array}$ \\
\hline 8 & Siswa & $\begin{array}{l}\text { NIS, IDKelas, NamaSiswa, } \\
\text { NamaAyah, NamaIbu, } \\
\text { NoHpOrtu1, NoHpOrtu2 }\end{array}$ \\
\hline 9 & Pesan Masuk & $\begin{array}{l}\text { IDPesanasuk, } \\
\text { TglWaktuPesanMasuk, NIS, } \\
\text { IsiPesan_M, StatusPesan_M }\end{array}$ \\
\hline
\end{tabular}

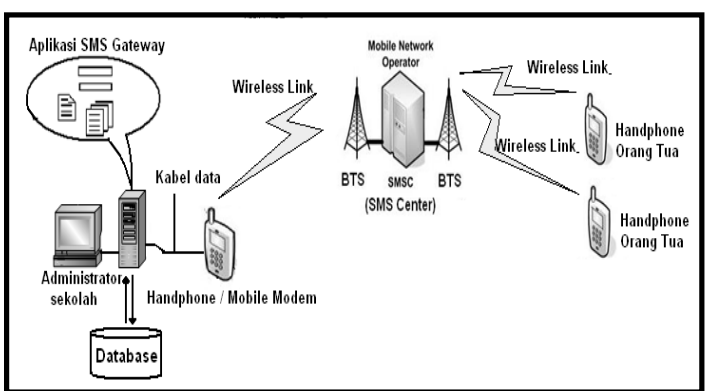

Gambar 3. Konfigurasi jaringan sistem

Tahapan yang akan dilakukan untuk mengidentifikasi kebutuhan use case dalam Sistem Informasi Distribusi Informasi Sekolah melalui SMS Gateway adalah dengan menentukan kandidat aktor dan use case requietment serta interaksi antara aktor-aktor terhadap use case-use case requirement. Aktor-aktor yang terdapat dalam sistem ini adalah administrator, sistem dan orang tua murid. Administrator memiliki hak akses terhadap sistem, melakukan penginputan data pengumuman Sekolah terbaru, simpan dan hapus data pengumuman serta melakukan pengiriman pesan ke orang tua murid. Orang tua murid memiliki hak untuk menerima broadcast SMS pengumuman Sekolah dan juga dapat 
melakukan request pengumuman Sekolah dengan cara mengirim pesan berisi format SMS yang telah ditentukan sebelumnya. Sistem menerima dan membalas request SMS orang tua murid sehubungan dengan permintaan pengumuman Sekolah.

TABEL IV ANALISA KEBUTUHAN PROSES

\begin{tabular}{|c|c|c|}
\hline No & Nama Proses & Diskripsi Proses \\
\hline 1 & Login & $\begin{array}{l}\text { Proses untuk menentukan hak akses } \\
\text { user untuk masuk ke dalam aplikasi } \\
\text { sistem distribusi informasi dan untuk } \\
\text { dapat menjalankan fungsi-fungsi di } \\
\text { dalam aplikasi tersebut. } \\
\text { Data Input : Username, Password } \\
\text { Aktor: Administrator }\end{array}$ \\
\hline 2 & $\begin{array}{l}\text { Mengelola } \\
\text { Pengumuman } \\
\text { Umum }\end{array}$ & $\begin{array}{l}\text { Proses untuk mengelola informasi } \\
\text { umum Sekolah berupa data } \\
\text { pengumuman libur, acara, lomba dan } \\
\text { himbauan Sekolah dengan cara } \\
\text { menambah data, kemudian } \\
\text { dikirimkan ke orang tua murid } \\
\text { Data Input: Isi Pesan } \\
\text { Aktor: Administrator }\end{array}$ \\
\hline 3 & $\begin{array}{l}\text { Mengelola } \\
\text { Pengumuman } \\
\text { Kelas }\end{array}$ & $\begin{array}{l}\text { Proses untuk mengelola informasi } \\
\text { kelas berupa data pengumuman } \\
\text { Tugas Harian dan Ulangan dengan } \\
\text { cara menambahkan data, kemudian } \\
\text { dikirimkan ke orang tua murid. } \\
\text { Data Input: Isi Pesan, Kelas } \\
\text { Aktor: Administrator }\end{array}$ \\
\hline 4 & $\begin{array}{l}\text { Mengelola } \\
\text { SMS Server }\end{array}$ & $\begin{array}{l}\text { Proses untuk melihat dan mengecek } \\
\text { pesan yang telah dikirim dan pesan } \\
\text { yang masuk ke dalam sistem. } \\
\text { Data Input: Tanggal Entri, Status } \\
\text { Aktor: Adminstrator }\end{array}$ \\
\hline 5 & $\begin{array}{l}\text { Request } \\
\text { Pengumuman } \\
\text { Umum }\end{array}$ & $\begin{array}{l}\text { Proses request Pengumuman Umum } \\
\text { dari orang tua murid ke Sekolah. } \\
\text { Data Input: Format SMS Request } \\
\text { Pengumuman Umum } \\
\text { Aktor: Orang tua murid }\end{array}$ \\
\hline 6 & $\begin{array}{l}\text { Request } \\
\text { Pengumuman } \\
\text { Kelas }\end{array}$ & $\begin{array}{l}\text { Proses request Pengumuman Kelas } \\
\text { dari orang tua murid ke Sekolah. } \\
\text { Data Input: Format SMS Request } \\
\text { Pengumuman Kelas } \\
\text { Aktor: Orang tua murid }\end{array}$ \\
\hline
\end{tabular}

Use Case diagram untuk Sistem Informasi distribusi informasi melalui SMS Gateway dapat dilihat pada Gambar 4. Setelah menganalisa use case diagram pada Gambar 4 maka dapat diketahui kebutuhan sistem dan ditentukan class apa saja yang diperlukan dalam sistem ini. Class diagram Sistem Informasi Distribusi Informasi Sekolah melalui SMS Gateway dapat dilihat pada Gambar 5 .

Pada class diagram yang dapat dilihat pada Gambar 5 terbentuk 9 class yaitu class TipePengumuman, class PengumumanUmum, class PesanKeluarUmum, class PengumumanKelas, class PesanKeluarKelas, class Kelas, class MataPelajaran, class Siswa dan class PesanMasuk.

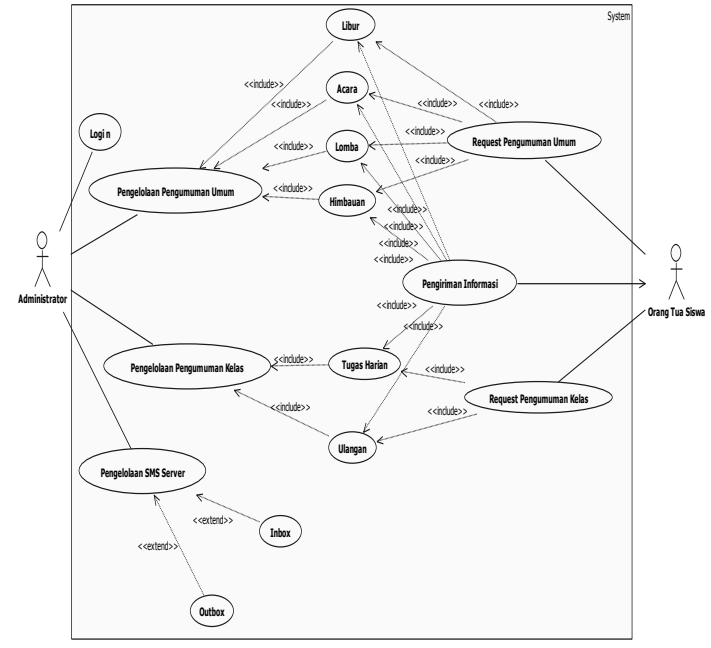

Gambar 4. Use case diagram

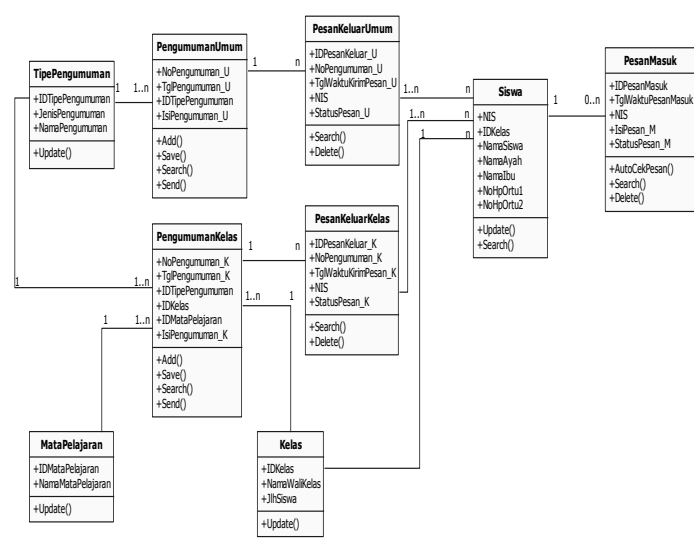

Gambar 5. Class diagram

Setiap proses pada use case diagram memiliki satu activity diagram. Activity diagram Pengumuman Umum - Libur dapat dilihat pada Gambar 6.

Setiap activity diagram disertai dengan satu sequence diagram untuk mengilustrasikan rentetan interaksi antara class atau objek setiap waktu. Sequence diagram Pengumuman Umum Libur dapat dilihat pada Gambar 7.

Urutan aktifitas yang dilakukan administrator untuk menambah dan mengirim pesan pengumuman sama dengan penjelasan yang dijabarkan peneliti pada activity diagram. Pada saat jendela Konfirmasi Pengumuman Libur Sekolah dimunculkan dan sistem menerima perintah Kirim Pesan dari administrator, sistem akan secara otomatis menambahkan dan menyimpan data pengumuman libur pada tabel Pengumuman Umum, kemudian mengakses semua nomor handphone orang tua murid yang tersimpan pada tabel Siswa di database untuk dikirimkan pengumuman libur sekolah. Setiap 
pesan pengumuman umum yang dikirim melalui sistem akan tersimpan di tabel Pesan Keluar Umum pada database. Hirarki aplikasi dari sistem yang dirancang dapat dilihat pada Gambar 8.
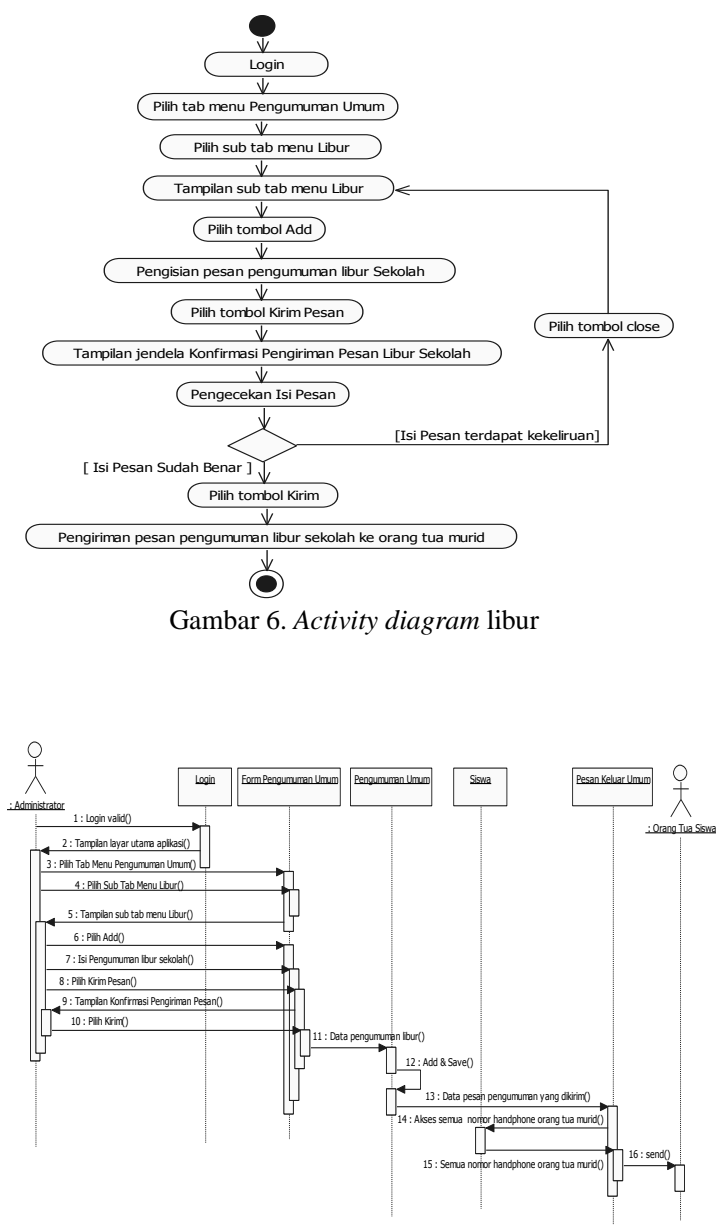

Gambar 7. Sequence diagram libur

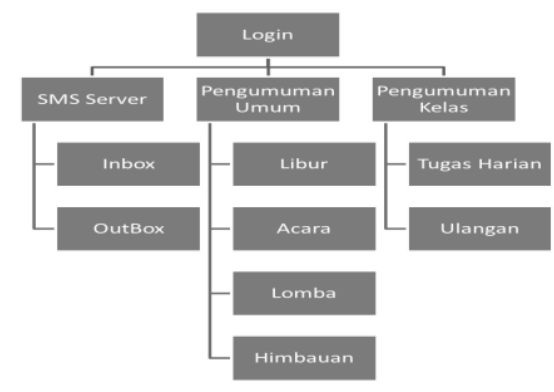

Gambar 8. Hirarki aplikasi

\section{Hasil dan Analisa}

Pada rancangan diagram hirarki aplikasi di atas, administrator harus mengisikan username dan password form login untuk dapat masuk kedalam sistem. Rancangan tampilan form login yang dapat dilihat pada Gambar 9.

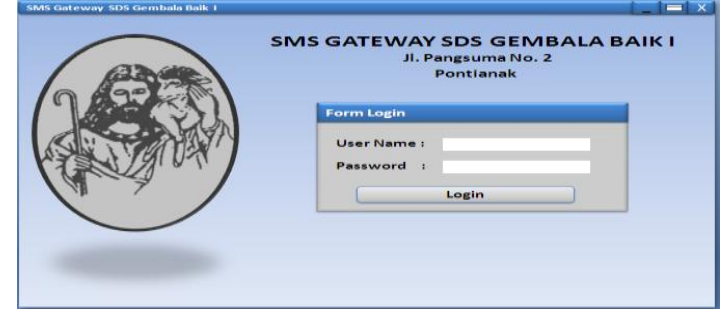

Gambar 9. Rancangan tampilan form login

Pada tampilan utama aplikasi SMS Gateway SDS Gembala baik I, terdapat tiga tab menu utama yaitu tab menu SMS Server, Pengumuman Umum dan Pengumuman Kelas.

Tab menu SMS Server terdiri atas sub tab menu Inbox dan Outbox, digunakan untuk mengelola SMS yang masuk ke sistem berupa request pengumuman dan SMS yang keluar dari sistem berupa hasil request pengumuman atau SMS yang dikirimkan secara broadcast oleh administrator ke orang tua murid sehubungan dengan pengumuman dari Sekolah. Rancangan tampilan Tab Menu SMS Server dapat dilihat pada Gambar 10.

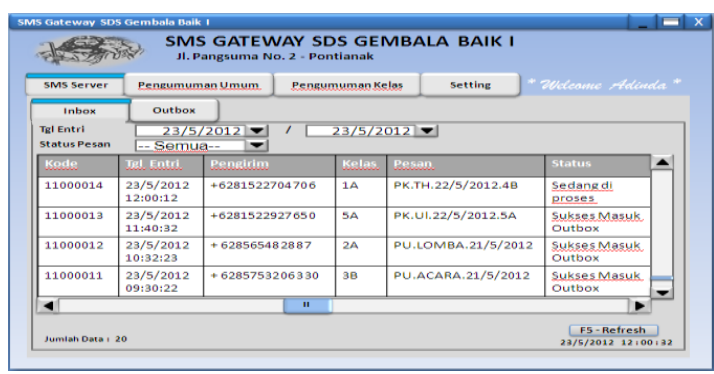

Gambar 10. Rancangan tampilan tab menu SMS server

Tab menu pengelolaan pengumuman umum terdiri atas sub tab menu Libur, Acara, Lomba dan Himbauan, digunakan untuk pengelolaan pengumuman umum berdasarkan tipe pengumuman masing-masing. Setiap sub tab menu terdapat kesamaan dari segi tampilan, tahapan-tahapan dalam broadcast pengumuman dan pencarian data pengumuman. Perancangan tab menu Pengumuman Umum dapat dilihat pada Gambar 11.

Tab menu Pengelolaan Pengumuman Kelas terdiri atas sub tab menu Tugas Harian dan Ulangan, yang digunakan untuk mengolah dan mengirim pengumuman yang berhubungan dengan informasi tugas kelas, jadwal ulangan harian dan jadwal ulangan umum. Perancangan sub tab menu Tugas Harian dan sub tab menu Ulangan dapat dilihat pada Gambar 12 dan 13. 


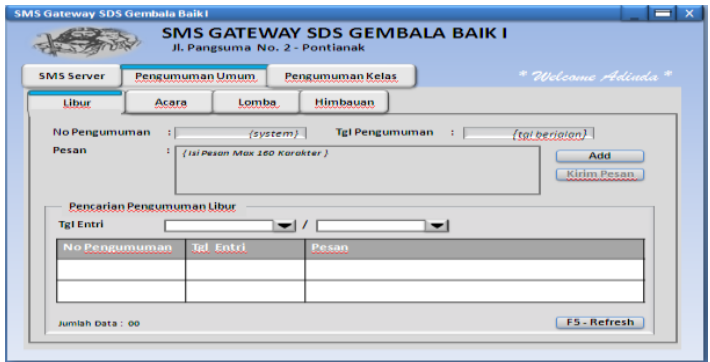

Gambar 11. Rancangan tampilan tab menu pengumuman umum

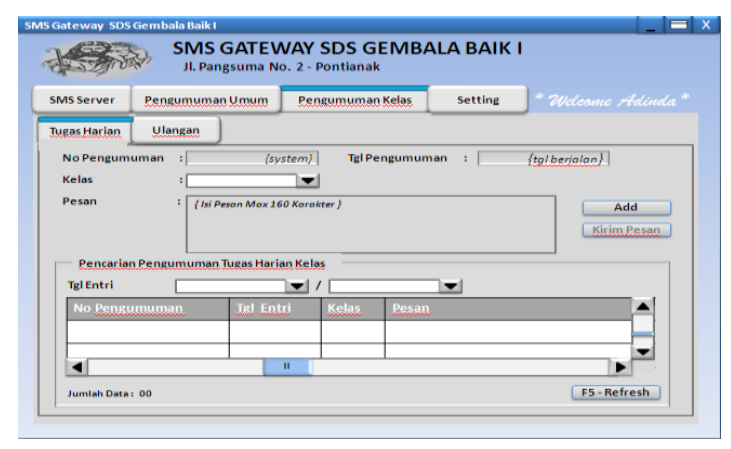

Gambar 12. Rancangan tampilan sub tab menu tugas harian

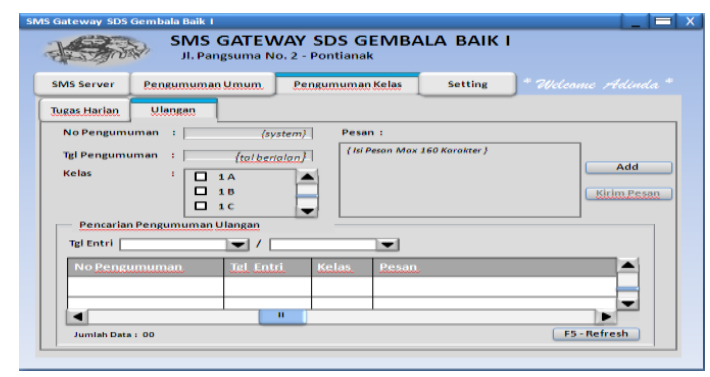

Gambar 13. Rancangan tampilan sub tab menu ulangan

Pendistribusian informasi sekolah melalui SMS Gateway memudahkan sekolah untuk menyampaikan berbagai informasi penting mengenai kegiatan belajar mengajar persekolahan kepada orang tua murid, baik dengan cara broadcast SMS atau sistem membalas secara otomatis (Auto Replay) SMS request pengumuman dari orang tua murid. Contoh tampilan SMS pengumuman libur sekolah dan pengumuman tugas harian yang diterima oleh handphone orang tua murid dapat dilihat pada Gambar 14.

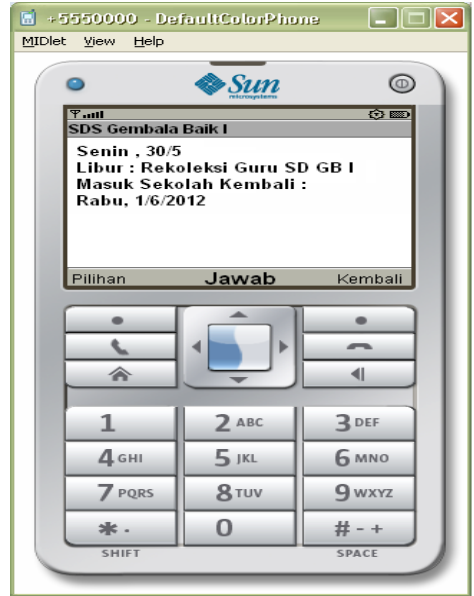

Gambar 14. Tampilan SMS pengumuman libur sekolah di handphone orang tua murid

Auto Replay SMS request pengumuman adalah layanan pengiriman pesan pengumuman oleh sistem sebagai balasan dari SMS request yang dikirimkan oleh orang tua murid. Rincian format SMS request Pengumuman Umum yang dapat dilihat pada Tabel V.

TABEL V

\begin{tabular}{lc}
\multicolumn{1}{c}{ FORMAT SMS REQUEST PENGUMUMAN UMUM } \\
$\begin{array}{l}\text { Format request } \\
\text { Pengumuman Umum }\end{array}$ & $\begin{array}{c}\text { Contoh SMS yang Masuk ke } \\
\text { Sistem }\end{array}$ \\
\hline $\begin{array}{l}\text { PU.LIBUR. } \\
\text { [tgl/bulan/tahun] }\end{array}$ & PU.LIBUR.17/05/2012 \\
$\begin{array}{l}\text { PU.ACARA. } \\
\text { [tgl/bulan/tahun] }\end{array}$ & PU.ACARA.21/05/2012 \\
$\begin{array}{l}\text { PU.LOMBA. } \\
\text { [tgl/bulan/tahun] }\end{array}$ & PU.LOMBA.21/05/2012 \\
PU.HIMBAUAN. & PU.HIMBAUAN.21/05/2012 \\
[tgl/bulan/tahun] &
\end{tabular}

Contoh tampilan SMS request dan SMS balasan pengumuman libur Sekolah di handphone orang tua murid dapat dilihat pada Gambar 15 . Rincian format SMS request Pengumuman Kelas dapat dilihat pada Tabel VI.

Contoh Tampilan SMS request dan SMS balasan pengumuman tugas harian di handphone orang tua murid dapat dilihat pada Gambar 16.

Diagram hubungan antar tabel merupakan model objek yang menggambarkan struktur hubungan antar tabel untuk memudahkan 
menganalisa relasionalitas tabel-tabel tersebut. Detail tabel (entity) dengan atribut (field) dapat dilihat pada Gambar 17.

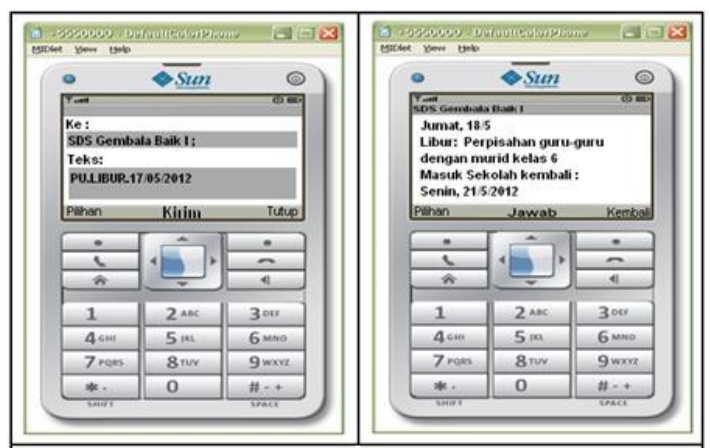

Gambar 15. Tampilan SMS Request dan SMS Balasan Pengumuman Libur Sekolah

TABEL VI

FoRMAT SMS REQUEST PENGUMUMAN UMUM

\begin{tabular}{ll}
\hline \multicolumn{1}{c}{$\begin{array}{c}\text { Format request } \\
\text { Pengumuman Kelas }\end{array}$} & \multicolumn{1}{c}{$\begin{array}{c}\text { Contoh SMS yang Masuk ke } \\
\text { Sistem }\end{array}$} \\
\hline PK.TUGAS. & PK.TUGAS.22/05/2012.1A. \\
[tgl/bulan/tahun]. & MTK \\
[kelas]. & \\
[matapelajaran] & \\
& \\
PK.ULANGAN. & PK.ULANGAN.12/05/2012. \\
[tgl/bulan/tahun]. & 5A.AGAMA \\
[kelas]. & \\
[matapelajaran] & \\
& \\
\hline
\end{tabular}

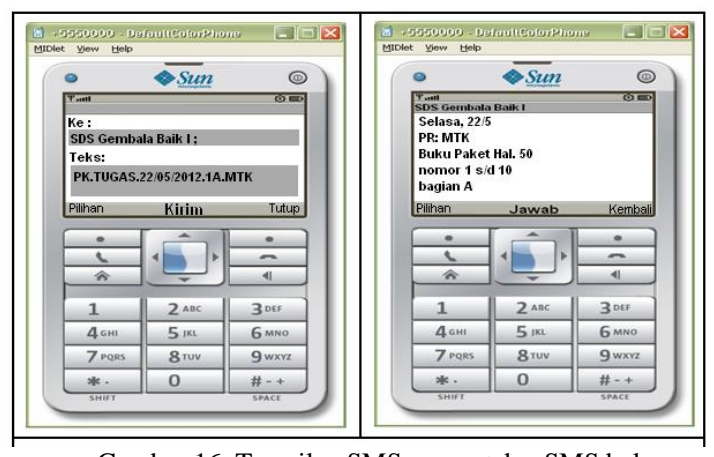

Gambar 16. Tampilan SMS request dan SMS balasan pengumuman tugas harian

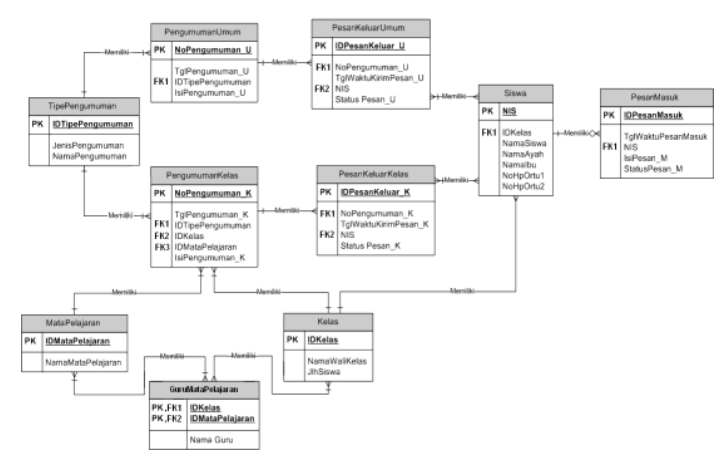

Gambar. 17. Entity Relationship Diagram
Perancangan sistem informasi distribusi informasi Sekolah melalui SMS Gateway ini adalah sebagai acuan yang terstruktur untuk pembuatan coding program dan uji coba pengembangan sistem informasi distribusi informasi pada SDS Gembala Baik I Pontianak.

Sistem informasi distribusi informasi Sekolah melalui SMS Gateway memberikan kemudahan bagi pihak Sekolah untuk menyampaikan informasi mengenai kegiatan belajar mengajar Sekolah dengan cepat, mudah dan langsung kepada orang tua murid. Orang tua murid juga dimungkinkan untuk mengakses informasi sekolah kapan dan dimana saja dengan cara mengirimkan SMS request pengumuman umum atau kelas dengan format yang sudah ditentukan sebelumnya.

\section{Kesimpulan}

Pada penelitian ini dihasilkan sebuah rancangan sistem informasi distribusi informasi sekolah melalui SMS Gateway dengan alur proses perancangan menggunakan pendekatan Zachman Framework. Perancangan dimulai dengan dengan melakukan identifikasi kebutuhan sistem yang dimodelkan dengan menggunakan Unified Modeling Language (UML), perancangan antar muka pengguna menggunakan Graphical User Interface (GUI) dan perancangan basis data.

Hasil dari perancangan Sistem Informasi distribusi informasi Sekolah ini mempunyai tiga tab menu utama berupa tab menu SMS Server, Pengumuman Umum dan Pengumuman Kelas. Tab menu SMS Server terdiri atas sub tab menu Inbox dan Outbox. Tab menu Pengumuman Umum terdiri atas sub tab menu Libur, Acara, Lomba dan Himbauan. Tab menu Pengumuman Kelas terdiri dari sub tab menu Tugas Harian dan Ulangan.

\section{Referensi}

[1] Romle, Amirul Azuani, \& Dalbri Singh, "Integrated Parent Information System (SMIB) to Increase Parental Involvement in Children's Learning Process in Malaysian Primary School", International Conference on Electrical Engineering and Informatics, pp. A40- A45, 2011.

[2] Ervasti, Minna Isomursu, \& Marianne Kinnula, "Experience form NFC Supported School Attendance Supervision for Childern", Third Conference on Mobile Ubiquitous Computing System, Service and Techologies, pp. 22-30, 2009. 
[3] R.I. Rosidi, Membuat Sendiri SMS Gateway Berbasis Protokol SMPP, ANDI, Yogyakarta, p.1-10, 2009.

[4] Triyono, "Pelayanan KRS On-line Berbasis SMS"." Jurnal Teknologi, Vol. 3, pp. 33-38. 2010.

[5] LiuYi \& Cheng Ping-guang, "Design and Implementation of School Management Service System", International Conferance Computer and Automation Engineering (ICCAE), pp. 596-600, 2010.

[6] A. Novianti \& Ami Fauzijah,"Sistem Informasi Sekolah Dasar Berbasis SMS." Seminar Nasional Aplikasi Teknologi Informasi 2009 (SNATI 2009), Yogyakarta, 2009. A40- A45.

[7] A. Ibrahim, "Pengembangan Sistem Informasi Monitoring Pengembangan Sistem Informasi Monitoring Tugas Akhir Berbasis Short Message Service (SMS) Gateway di Fasilkom Unsri", JUSI, vol.1, pp.81-92. 2011.
[8] A. Rohiza, Aliza Sarlan, et.al, "SMS-Based Final Exam Retrieval System on Mobile Phones", International Conferance Information Technology (ITSim), pp.1-5. 2010.

[9] Berthelsen, Donna, and Sue Walker, "Perent Involvement in their children's education", Australian Institute of Family Studies, Australia, p.3, 2008.

[10] Wahidin, Aplikasi SMS dengan PHP untuk Orang Awam, Maxikom, Palembang, p.153, 2010.

[11] Graha, Chairinniza. Keberhasilan Anak Ditangan Orang Tua. PT Elex Media Komputindo, Jakarta, p.97-98, 2007.

[12] S. F. bin Haji Sidek, "The Development of the Short Messaging Service (SMS) Application For The School Usage", International Simposium Information Technology (ITSim), pp.1382-1386. 2010. 